\title{
Ownership Concentration and Economic and Financial Performance in Latin-American Companies
}

\author{
Tarcísio Pedro da Silva ${ }^{1}$, Maurício Leite ${ }^{1}$, Jaqueline Carla Guse ${ }^{1} \&$ Tania Cristina Chiarello ${ }^{1}$ \\ ${ }^{1}$ Universidade Regional de Blumenau - FURB, Blumenau, Santa Catarina, Brazil \\ Correspondence: Maurício Leite, Rua Antônio da Veiga, 140, Sala D202 - Victor Konder, CEP: 89.031-900 - \\ Blumenau/SC, Brazil.
}

Received: August 19, 2018

Accepted: September 27, 2018

Online Published: October 11, 2018

doi:10.11114/bms.v4i4.3681

URL: https://doi.org/10.11114/bms.v4i4.3681

\begin{abstract}
The study examined the relationship of ownership concentration in the economic and financial performance of publicly traded Latin American companies possessing American Depository Receipts (ADRs). Generally, the capital structure decisions are tied directly to the results of the organizations, thus reflecting the economic and financial performance. The correlation between the set of variables within the group of ownership structure with the group of economic and financial performance showed significant correlation with the linear combinations, when analyzed in the set of all the samples of companies and taken separately by country. However, the results did not show similar correlation to Venezuela, Colombia and Peru due to the existence of few observations. The results also portrayed a significant correlation within economic and financial performance, higher to Mexican companies, when compared with the results of other countries and among the set of the two groups of variables that highlighted the analysis by ownership structure and economic and financial performance as well.
\end{abstract}

Keywords: ownership concentration, economic and financial performance, canonical correlation

\section{Introduction}

Understanding the ownership structure is an important factor for business management, since it directly influences its efficiency by means of corporate control, a fact that contributes to the disclosure of the degree of risk diversification to shareholders (LEAL; SILVA; VALADARES, 2002). Silveira et al. (2004) argue that another factor influencing the capital structure occurs in the relationship of agency conflict within public traded companies between controlling and minority shareholders, because of the presence of ownership structure. This conflict is reinforced by the separation between both control rights and rights to the cash flow through the issuance of two classes of shares, with or without voting rights.

Okimura (2003) asserts that the controlling power of the controlling shareholder enables the use of the company's resources for its own benefit, while the other shareholders of the company partially bear the costs. This occurs since the transfer of the company's resources by the controlling shareholder can occur through several mechanisms such as perks, excessive wages to both shareholders and relatives, underinvestment, contracts and transactions favoring interested parties, among others. The author also adds that the problem of expropriation might be more pronounced when the controlling shareholders participate in the management team of the company, especially if they have more rights control than rights on cash flow.

Considering the asymmetry of information, Srour (2005) points out that the lack of transparency within the organizations and misconduct against the minority shareholders have been consistently identified as sources for poor performance in stock market, thus causing serious consequences for the efficiency of economy. Good projects cease to be funded when the firm is not committed to protecting the interests of its investors.

Bastos, Nakamura and Basso (2009) insist that the determinants of capital structure are not only restricted to specific factors of the companies. They include, among others, level of tangibility, size, profitability, risk, growth opportunities, level of income tax and tax benefits. Still, the environment in which the firm operates is another factor determining the level of its indebtedness. In this regard, Terra (2007) states that country-specific factors are important determinants of capital structure in emerging markets. These specific factors include institutional infrastructure, legal and accounting practices, financial infrastructure and macroeconomic environment. 
As Céspedes, Gonzalez and Molina (2009) warn, Latin American companies showing high growth opportunities tend to have higher leverage. The authors argue that high levels of ownership concentration in Latin American companies have a positive relationship with leverage, thus indicating that firms with high ownership concentration do not seek capital funding to avoid losing control of the company.

Given the evidences obtained by studies on ownership structure and their implications, become relevant researches describing the influence of the ownership structure within Latin American companies. Thus, this study seeks to answer the following question: which is the relationship of ownership concentration in the economic and financial performance of Latin American companies? The main objective of the research is to examine the relationship of ownership concentration in the economic and financial performance in Latin American companies. For the execution of this study was used a sample of Latin American publicly traded firms possessing American Depository Receipts (ADRs), a factor involving more rigid instruments of protection of minority shareholders.

This study is justified as it intends to advance the analysis of traditional determinants of ownership structure aiming at investigating whether these structures exert influence on the economic and financial performance of companies in Latin America. According to Terra (2007), the countries chosen are particularly interesting for the problem in question for, besides being good examples of emerging economies, they have gone through a variety of macroeconomic environments in a relatively short period of time. The author adds that the macroeconomic conditions are somehow important for capital structure decisions. So, it is likely that Latin American companies have experienced these effects. Also, Céspedes, Gonzales and Molina (2009) suggest that Latin American market shows an ideal place for the study of the effect of ownership concentration on the leverage, given the high ownership concentration in the companies that are in the region.

Capobiango et al. (2012) explain that in the current economic environment in which competitiveness among companies struggling to stay in business, studies that aim at providing information necessary for such organizations may be aware of how healthy they are. Thus, they contribute to their stay active, thus enabling managers to make decisions based on information that will give them more security and direction to achieve the results that will contribute to the generation of wealth within the organizations.

The period under analysis comprises five years, from 2008 to 2012, due to the availability of information that supported the study, since a greater period would reduce the sample size, which would harm the data analysis. This limitation has diminished the total analysis period compared to the longitudinal study of Marcon et al (2007), which used the period from 1996 to 2005. However, several studies on economic and financial performance and capital structure, as those of Roque and Cortez (2006), Costa and Garcias (2009), Nakamura et al. (2009), among others, have used the period of five years for analysis, thus proving to be an efficient period for analysis. Assaf Neto (2012) highlights the importance of an analysis with temporal comparison to enable monitoring of the indicators' evolution. The occurrence is usually three to five years.

\section{Theoretical Framework}

This review of literature deals with themes underlying the research problem in question. Initially, information about the ownership structure of organizations is displayed, which is the interest of the research, followed by discussion of indicators of economic and financial performance in which arguments to use the variables chosen for the study are discussed. This theoretical foundation is completed by studies investigating the ownership structure and economic and financial performance of organizations as well. The searching bases of bibliographic data used in this research were SPELL - Scientific Electronic Library Periodicals, Scopus - Document Search, Science Direct, JSTOR and Capes Portal of Journals.

\subsection{Ownership Structure}

The argument that it does not matter how the company structures its sources of funding is one of the classic theories that influence up to the present day the discussions on capital structure. This theory was proposed by Modigliani and Miller (1958) under the assumptions of an efficient market, in which there would be no optimal capital structure. All possible combinations of debt and equity would lead the company to the same weighted average cost of capital and same value.

However, as pointed out by Miller (1977), the behavior of interest rates should provide a basis for the choice of an optimal capital structure. The value of the company may be increased using debt, since interest payments can be deducted from taxable income of companies. Even in a world in which interest payments are deductible in calculating corporate income tax, the value of the company will still be independent of its capital structure.

Since then, Myers (1984) divides the theory of capital structure into two streams. Static Trade Off characterizes as optimal capital structure the balance between the tax benefits of debt and its bankruptcy costs associated with leverage. In this approach, the limit for the use of debt is given when borrowing costs become greater than the benefits generated 
by the debt. The other stream, Pecking Order Theory, argues that the company adopts a logical sequence to establish its capital structure, departing from the internal funds, financing and, finally, the issuance of shares.

The presence of shareholders with large ownership stake can be detrimental to a company, since the interests of these controlling shareholders may not be aligned with the rest of the shareholders. On the other hand, one of the benefits associated with the presence of large shareholders relates to the mitigation of the problem of monitoring the administration, with the intention to reduce agency costs.

Leal, Silva and Valadares (2002) argue that much of the literature that studied the problem of separation of ownership from control did that within an environment marked by large number of small shareholders, each of them with a very small amount of capital, and few are the countries that are characterized by this diffuse ownership structure. These authors add that the high concentration of ownership and control occurs primarily in large corporations from countries of Anglo-Saxon legal tradition such as France, Italy and Germany, among others. In Brazil, shares without voting rights are heavily utilized.

The ownership structure of a company is determined by the concentration of ownership and the identity of its majority shareholder, which refers to the percentage of shares of the majority shareholder or a group. Campos (2006) warns that such shareholder or group can be a family, the government, a bank, an institutional investor or a non-financial company. These are the categories used in the definition of identity.

The study of Perobelli and Fama (2003) has shown the factors inducing the indebtedness of publicly traded companies in Latin American countries like Mexico, Argentina, Brazil and Chile. The results showed that the inductive factors vary according to the country. Procianoy and Schnorrenberger (2004) assert that the structure of control significantly influences in the capital structure decisions of organizations. According to them, although the theory of finance has advanced this type of research, the results have pointed to several sides the reasons why managers make decisions concerning capital structure.

Okimura (2003) believes that the literature brings extensive documentation related to both the advantages or benefits, the disadvantages or costs, associated with the ownership concentration within companies. The presence of controlling shareholders, the level of rights concentration and control are doubly associated with the costs and benefits to the company, together with the net effect on the value and performance of the companies.

Leal and Saito (2003) suggest that in countries like Brazil control is very concentrated and controllers can easily monitor the managers. Management and control are often exercised by the same people, even in the largest publicly traded companies. The authors insist that such a phenomenon highlights the conflict between controlling shareholders and minority shareholders. The central policy problem in recent times has been to protect minority shareholders against predatory acts perpetrated by the controlling shareholders.

Another example worth mentioning is that Chile's controlling conglomerates rely on a relatively small number of people to conduct business. They, in general, exclusively engage as members of the board of companies affiliated to their groups. However, Chilean conglomerate controllers have more equity than strictly necessary for the control, suggesting that the benefits of cash flow associated with subsidiaries are relatively large (LEFORT; WALKER, 2000).

According to Silveira et al. (2004), the benefits of having a large shareholder are reduced. This happens largely because, despite the high concentration of common stock, the issuance of a high percentage of shares without voting rights and the use of pyramid schemes lead many controllers to become, indeed, minority shareholders of subsidiaries, because they do not hold greater part of the share capital of the company. However, this situation generates a combination of great power and low allocation of own resources in the company, thus reducing the benefits of having a controlling shareholder and increasing the potential for expropriation of the minority shareholders.

Regarding the structures of ownership, the control and performance of companies, evidence has indicated in general a negative impact of discrepancy on the rights on operating performance and value of the companies (ALDRIGHI; MAZZER NETO, 2005). Fronningen and Wijst (2009) argue that ownership structures are chosen to maximize the company's value at a given combination of characteristics of the firm and its environment.

According to Silva, Majluf and Paredes (2006), in Chile's companies, the control structure of ownership, i.e., the economic rights and voting rights, affects the performance of the companies. The author argue that social ties improve performance not only when the concentration of voting rights is low but also when the voting rights of controlling shareholders are aligned with their economic rights. In Brazil, the structure of share ownership is predominantly concentrated (DAMIL, ROGERS AND RIBEIRO, 2007). According to Leal et al. (2002), the control of the companies on average is dominated by the three largest shareholders.

Bastos's and Nakamura's (2009) study has investigated the determinants of capital structure for a sample of 297 companies from various sectors in Brazil, Mexico and Chile, between 2001 and 2006. Departing from six indicators of 
debt it was evident that factors such as current liquidity, profitability, market to book value and size have showed the most significant results for the capital structure of the companies in the three countries. The four theoretical perspectives analyzed are: (1) trade off, (2) information asymmetry, (3) pecking order and (4) agency theory. The theory of pecking order seems to be the one that best explains the results for Brazil and Mexico. For Chile, besides pecking order, the theory of trade off strongly influences the capital structure.

Researches conducted by Céspedes and González (2009) have evaluated the determinants of capital structure within Latin American companies using a sample of seven countries. The authors have found evidence that the companies in the region show levels of debt like North American firms. This fact, to the authors, is intriguing because Latin American companies show relatively lower tax benefits and higher costs of bankruptcy. Thus, the companies have concentrated ownership and have avoided issuing shares, for they do not want to share property rights. The results depict a positive relationship between leverage and ownership concentration, when the loss of control becomes a problem.

\subsection{Corporate Performance}

Weston (1974) states that the world's economic development has introduced new instabilities, anticipating, and adjusting itself to, changes in the financial environment, and adopting an international dimension to become an integral part of the financial management. The finance theory provides a framework for understanding the role played by the funding instruments and institutions.

Myers (1977) points out that there is an important gap in the theory of finance regarding the issues of corporate debt policy. He defends that the theory should be able to explain why the tax advantages of debt financing does not lead companies to borrow as much as possible. From this perspective, the theory should explain also why some companies take funding more than others, why some take short-term loans, and others make use of long-term instruments. Myers also asserts that the debt of a company can be large enough to prevent it from raising funds to finance new projects.

According to Lang, Ofek and Stulz (1996) the capital structure indicates that the managers of firms with good growth opportunities should choose lower leverage. These companies may not be able to take advantage of their investment opportunities if they have access to external funding. As a result, a negative relationship between leverage and future growth may arise because the managers of firms with good growth opportunities tend to choose low leverage.

Shyam-Sunder and Myers (1999) suggest that Pecking Order theory does not define an optimal level of indebtedness. The debt changes due to the imbalance of internal cash flows and investment opportunities. While several regions of the world are increasingly integrated and protectionist within this environment of extreme competition, the executive needs better tools to define and apply their strategies to get best performance of the organizations (FISCHMANN; ZILBER, 1999).

Simerly's and Li's (2000) see positive relationship between leverage and performance within the firms operating in relatively stable environments. Consequently, financial institutions can be better sources of finance for risky projects. Besides, the stock market can become a better source of financing within unstable economic environments. Gomes and Leal (2001) state that the Pecking Order theory should establish a positive relationship between the level of growth and the debt of the companies. They justify this claim by arguing that companies with higher growth rates require more resources than they can generate and tend to seek outside the company the resources necessary for its expansion.

The company's performance is directly related to the decision-making process of the managers. Assaf Neto (2003) asserts that the performance and continuity of any business depend on the quality of the decisions made by the administration's officials. These decisions should be based on the internal and external environment of the organization.

Perobelli and Fama (2003) argue that investment decisions should not be taken without regard to financing costs, calculated from the combination of debt and equity, due to its relative importance to financing decision within the theory of finance. The decision to combine debt and equity with investment decision and the decision to distribute results make the basis of corporate finance.

The financial statement analysis aims at better assessing the performance of companies to identify the results of the various financial decisions taken (ASSAF NETO, 2003). In this regard, Iudícibus (2008) considers that the analysis techniques of financial statements by means of indices are one of the most important developments in accounting. These techniques help the analyst report what happened in the past and allow him to infer what can happen in the future.

The financing indexes can be divided into four groups: liquidity indexes, activity indexes, debt indexes and profitability indexes. The first three ones mainly measure the risk, while the profitability indexes calculate the return. The liquidity, activity and profitability indexes are important categories for short-term analysis, since the debt indexes are interesting mainly for long-term analysis (GITMAN, 2004). 
As Gitman (2004) puts it, companies have many different uses for the records and reports of their financial activities. It is necessary to prepare and deliver reports to regulatory institutes, lenders, owners and managers. The information contained in the financial statements is extremely important to these groups as they build measures of efficiency on it. The author argues that the relative efficiency is based on the use of indexes. The analysis of these indexes involves methods of calculations and interpretations designed to analyze and monitor a company's performance.

Perez and Fama (2004) assert that the analysis of economic and financial performance allows an evaluation of the company concerning its past activities and planning of future actions. A good economic and financial performance portrays the situation of the company's sustainability in the environment in which it operates. According to Ferreira (2005), the analysis of financial statements can be made comparatively considering a period. It includes the income statement of operations, balance sheet of its assets and liabilities, statement of source and application of its resources, the analysis of flow of cash of the operations. The author adds that the comparison of financial statements for several years reveals the direction, the speed and the extent of the trend lines.

The analysis of business performance has been an important field of the organizational studies and researches. They have shown several questions ranging from the concepts of profit generation and value addition to issues relating to the internal dimensions that can affect the economic and financial performance (CAMPOS, 2006).

From Bhagat's and Bolton's (2008) viewpoint, a company's performance can be a determinant of property, mainly for reasons related to this performance-based remuneration and privileged information. They argue that the superior performance of the company leads to an increase in the value of share options held by the management that, if exercised, would increase its share participation. Furthermore, if there are differences of information regarding the expectations of the future performance of the company in the market, then the holders of information have incentives to adjust their property in relation to the expected future performance.

Gartner (2010) believes that the economic and financial indexes summarize the results achieved by the strategic decisions. Consequently, they become important for supporting new business while the information is used to make decisions within the companies. Besides, the information also feeds analysis and decision-making processes that occur externally, involving groups that have interests in the corporation, but which usually do not participate in the decision-making process.

Regarding the economic and financial performance, Sousa Neto and Martins (2011) associate the company's performance with management and organization, through policies used by managers in the way they assess the market to make their decisions. Thus, performance is measured or evaluated by the results achieved in each period and reflects the company's performance.

Brigham and Ehrhardt (2012) suggest that the need of operational capital within a company often requires raising external resources through a combination of equity and debt, and this combination is called capital structure. Thus, they argue that the decision on the capital structure of a company includes choosing an ideal capital structure, average maturity of its debt, specific types of funding, besides the operational decisions that managers make to increase the company's value.

With respect to recent studies, some measurements of financial and economic performance were made by means of the debt and profitability across the set of companies from Brazil, Argentina and Chile, as shown in the research conducted by Marcon et al. (2007). The researchers used debt indicators on equity, operational return on total assets and net return on equity, which have captured the effects of the investment and financing strategies undertaken by managers. The results indicated that Brazilian firms have higher debt index in relation to Chilean and Argentine companies and, therefore, show worse performance. They have also found differences in the debt and performance between Brazilian and Chilean firms and between Brazilian and Argentine companies, but the data show no differences between Argentine and Chilean companies.

Santos, Pimenta Júnior and Cicconi (2009) believe that the use of debt generates two opposite effects. The positive effects of debt result from the tax benefit obtained by deducting the payment of corporate income tax of debt interest. The negative effects come from bankruptcy costs.

In their studies, Céspedes, Gonzales and Molina (2009) point out that attributes such as size, growth opportunities, asset tangibility, profitability and taxes are statistically and economically important to explain leverage in Latin American companies. The companies have high growth opportunities and those that are less profitable tend to have higher debt.

Researching on the determinants of ownership concentration within Chile's market, Morales, Meléndez and Ramírez (2013) have found that there is a higher level of financial leverage arising from bank loans, thereby reducing the need for more minority shareholders to finance new investment projects. They argue that a higher level of debt can be directly related to the concentration of ownership. 
For Correa, Basso and Nakamura (2013) the capital structure has been the subject of several studies over the past decades. The diversity of results leads to the conclusion that it is an unresolved issue. The discussions concerning the results of major studies published on the topic have been raising questions about the relevance or not of capital structure to firm's value.

\section{Method}

To analyze the relationship of ownership concentration with the economic and financial performance within Latin American companies was held a descriptive research with quantitative approach, through documentary research.

The descriptive aspect is observed in the discussion of corporate performance, thus providing a description of the sample analyzed. According to Gil (2011), a descriptive research has as its primary objective the description of the characteristics of a given population, phenomenon, or the establishment of relationships within variables.

Regarding its procedures, the research is classified as documentary, as it uses information contained in the financial statements of the companies. Cervo, Bervian and Silva (2007) understand that the documentary or bibliographical research seeks to explain a problem based on theoretical references derived from books, published articles, theses or dissertations.

As for the method, the study is classified as quantitative. According to Collis and Hussey (2005), a quantitative research is more objective, focusing on the measurement of phenomena. For this to occur adequately both collection of numerical data and statistical calculation were applied.

\subsection{Population and Survey Sample}

The objective of the research is to analyze the relationship between ownership structure and economic and financial performance in Latin American public traded companies. Within the universe of public traded companies in Latin America, were sought those with American Depositary Receipts (ADRs), regardless of the emission level and sector of activity, whose negotiations are active on the Stock Exchanges of New York (NYSE), American Stock Exchange, (AMEX) and National Association of Securities Dealers Automated Quotation (NASDAQ), active in 2014.

The choice of this group of companies is because the firms issuing ADRs must fit the strictest standards of Corporate Governance. Besides, it must provide on average better quality of governance than those from their country of origin, as shown by Silveira (2004).

The universe of companies with these characteristics was restricted to the following countries: Argentina, Brazil, Colombia, Chile, Mexico, Peru and Venezuela. They represent the most part of Latin American firms, which have issued ADRs. 38 companies were excluded because they did not have all the data for the five years analyzed. After applying these criteria, the sample was composed of 78 companies within the population of companies used in the research, as discriminated in Table 1. 
Table 1. Population of the companies used in the research

\begin{tabular}{|c|c|c|c|}
\hline Companies & Country & Companies & Countries \\
\hline Alto Palermo SA (APSA) & Argentina & Teka-Tecelagem Kuehnrich SA & Brasil \\
\hline Cresud SA & Argentina & Telefônica Brasil SA & Brasil \\
\hline Empresa Distribuidora y Comercializadora & Argentina & TIM Participações SA & Brasil \\
\hline Nortel Inversora SA & Argentina & Tractebel Energia SA & Brasil \\
\hline Pampa Energia SA & Argentina & Usinas Sider. de Minas Gerais SA & Brazil \\
\hline Ternium SA & Argentina & Vale SA & Brazil \\
\hline Transportadora de Gás Del Sul SA & Argentina & Companhia Cervecerias Unidas SA & Chile \\
\hline YPF SociedadeAnônima & Argentina & Embotelladora Andina SA & Chile \\
\hline AESTiete SA & Brazil & Empresa Nacional de Elect. SA & Chile \\
\hline ALL América Latina Logística SA & Brazil & Enersis & Chile \\
\hline Bombril SA & Brazil & Inversiones Aguas Metropolitanas SA & Chile \\
\hline Braskem SA & Brazil & Latam Airlines Group SA & Chile \\
\hline Centrais Elétricas de Santa Catarina SA & Brazil & Vina Concha y Toro SA & Chile \\
\hline CESP-Comp. Energética de São Paulo & Brazil & Cementos A Srgos SA & Colombia \\
\hline Cia Brasileira de Distribuição & Brazil & Ecopetrol SA & Colombia \\
\hline Cia de Saneamento Básico de São Paulo & Brazil & America Movil S.A.B. de C.V. & Mexico \\
\hline Cia de Transmissão de Energia Elétrica & Brazil & Coca-Cola Femsa S.A.B. de C.V. & Mexico \\
\hline Cia Energética de Minas Gerais & Brazil & Consorcio Hogar S.A.B de C.V. & Mexico \\
\hline Comp. de Transmissão - Paulista & Brazil & Corporacion Geo Sab de CV & Mexico \\
\hline Comp. Paranaense de Energia-Copel & Brazil & Desarrolladora Homex S.A.B de C.V. & Mexico \\
\hline Companhia Energética de São Paulo & Brazil & Empresas Ica S.A.B de C.V. & Mexico \\
\hline Companhia Siderúrgica Nacional & Brazil & Farmácias Benavides S.A.B. de C.V. & Mexico \\
\hline Companhia Paranaense de Energia Copel & Brazil & Fomento Econômico Mexicano SA & Mexico \\
\hline CPFL Energia SA & Brazil & Gruma S.A.B. de C.V. & Mexico \\
\hline CR2 Empreendimentos Imobiliários SA & Brazil & Grupo Aeroportuario Del Centro Norte & Mexico \\
\hline Diagnósticos da América SA & Brazil & Grupo Carso, S.A.B. de C.V. & Mexico \\
\hline Embraer SA & Brazil & Grupo Herdez S.A.B. de C.V. & Mexico \\
\hline Fibria Celulose SA & Brazil & Grupo Minsa S.A.B. de C.V. & Mexico \\
\hline Gerdau SA & Brazil & Grupo Simec S.A.B. de C.V. & Mexico \\
\hline Gol Linhas Aéreas Inteligentes SA & Brazil & Grupo Televisa S.A B & Mexico \\
\hline Iochpe-Maxion SA & Brazil & Grupo Tmm S.A.B. de C.V. & Mexico \\
\hline Klabin SA & Brazil & Industrias Bachoco S.A.B de C.V. & Mexico \\
\hline OI SA & Brazil & Maxcom Telecomunicaciones & Mexico \\
\hline Paranapanema SA & Brazil & Sare Holding SA & Mexico \\
\hline Petróleo Brasileiro SA - Petrobras & Brazil & Companhia de Minas Buenaventura SA & Peru \\
\hline Prumo Logística SA & Brazil & Union Andina de Cementos SA & Peru \\
\hline Rossi Residencial SA & Brazil & Ceramica Carabobo Saca & Venezuela \\
\hline Saraiva SA Livreiros Editores & Brazil & Corimon, SA & Venezuela \\
\hline Suzano Papel e Celulose SA & Brazil & Dominguez \&Cia SA & Venezuela \\
\hline
\end{tabular}

Source: Research data

Table 1 - population of companies used in the research - presents a set of companies, with higher number of 37 firms from Brazil, 19 from Mexico, 8 from Argentina, seven from Chile, three from Venezuela, and from Colombia and Peru, 2 each. The data related to the economic and financial indexes are of primary character. The collection was made on Thomson $^{\circledR}$ data basis for the period of 5 years, from 2008 to 2012. Data collection took place in March 2014 and the monetary values are presented in U.S. dollars, displayed directly by the Thomson ${ }^{\circledR}$ base.

\subsection{Procedures for Data Collection and Analysis}

To achieve the goal of analyzing the relationship of ownership concentration in Latin American companies' performance was used the method of canonical correlation. Spiegel (1993) defines correlation as the degree of relationship among the variables, determining how a linear equation, explains the relationship among the variables. Correlation analysis is applied aiming at measuring the strength of the association among numerical variables. The variables used in the study are shown in Table 2, titled 'variables used in the study'. 
Table 2. Variables used in the study

\begin{tabular}{|c|c|c|c|}
\hline Variables & & Proxy & Authors \\
\hline \multirow{8}{*}{ Property Structure } & Tangibility & $\begin{array}{l}(\text { Stock }+ \text { immobilized }) / \\
\text { total assets }\end{array}$ & $\begin{array}{c}\text { Titman, Wessels (1988); } \\
\text { Perobelli, Famá (2002 and 2003); } \\
\text { Bastos, Nakamura (2009); Bastos, } \\
\text { Nakamura, Basso (2009); } \\
\text { Espinola (2013) }\end{array}$ \\
\hline & $\begin{array}{l}\text { Assets' Side } \\
\text { Value }\end{array}$ & $\begin{array}{l}\text { Intangible Assets/Total } \\
\text { Assets }\end{array}$ & $\begin{array}{c}\text { Titman, Wessels (1988); Kayo } \\
\text { (2002) }\end{array}$ \\
\hline & $\begin{array}{l}\text { Other tax } \\
\text { benefits than } \\
\text { indebtedness } \\
\text { (OBFNE) }\end{array}$ & Depreciation/ Total Assets & $\begin{array}{c}\text { Titman, Wessels (1988); } \\
\text { Perobelli, Famá (2002 and 2003); } \\
\text { Kayo (2002) }\end{array}$ \\
\hline & Singularity & $\begin{array}{l}\text { (Selling Expenses/ Net } \\
\text { Sales) }\end{array}$ & $\begin{array}{c}\text { Titman, Wessels (1988); } \\
\text { Perobelli, Famá (2002 and 2003); } \\
\text { Kayo (2002) }\end{array}$ \\
\hline & Size & LN of Total Assets & $\begin{array}{l}\text { Titman, Wessels (1988); } \\
\text { Perobelli, Famá (2002 and 2003); } \\
\text { Kayo (2002); Bastos e Nakamura } \\
\text { (2009); Bastos, Nakamura, Basso } \\
\text { (2009); Espinola (2013) }\end{array}$ \\
\hline & $\begin{array}{l}\text { ETC: Total } \\
\text { Indebtedness }\end{array}$ & $\begin{array}{c}\text { (Current } \\
\text { Liabilities+Long-Term } \\
\text { liabilities)/Total Assets }\end{array}$ & $\begin{array}{c}\text { Bastos, Nakamura (2009); Bastos, } \\
\text { Nakamura, Basso (2009); } \\
\text { Espinola (2013) }\end{array}$ \\
\hline & $\begin{array}{l}\text { ECPC: } \\
\text { Short-Term } \\
\text { Indebtedness }\end{array}$ & $\begin{array}{l}\text { Current Liabilities/Total } \\
\text { Assets }\end{array}$ & $\begin{array}{c}\text { Bastos, Nakamura (2009); Bastos, } \\
\text { Nakamura, Basso (2009); } \\
\text { Espinola (2013) }\end{array}$ \\
\hline & $\begin{array}{l}\text { ELPC: } \\
\text { Long-Term } \\
\text { Indebtedness }\end{array}$ & $\begin{array}{c}\text { Long-Term } \\
\text { Liabilities/Total Assets }\end{array}$ & $\begin{array}{c}\text { Bastos, Nakamura (2009); Bastos, } \\
\text { Nakamura, Basso (2009); } \\
\text { Espinola (2013) }\end{array}$ \\
\hline \multirow{4}{*}{ Economic and Financial Performance } & OPTA & $\begin{array}{l}\text { Operacional Profit/Total } \\
\text { Assets }\end{array}$ & $\begin{array}{c}\text { Perobelli, Famá (2003); } \\
\text { Procianoy, Schnorrenberger } \\
\text { (2004) }\end{array}$ \\
\hline & $\begin{array}{c}\text { Return on } \\
\text { Assets (ROA) }\end{array}$ & Net Income /Total Assets & $\begin{array}{c}\text { Omran, Ragab (2004); Soares } \\
\text { (2006); Perucelo, Silveira, Espejo } \\
\text { (2009); Bastos, Nakamura (2009); } \\
\text { Bastos, Nakamura, Basso (2009); } \\
\text { Gartner (2010) }\end{array}$ \\
\hline & $\begin{array}{c}\text { Return on } \\
\text { Equity (ROE) }\end{array}$ & Net Profit/Equity & $\begin{array}{l}\text { Omran, Ragab (2004); Soares } \\
\text { (2006); Perucelo, Silveira, Espejo } \\
\text { (2009); Gartner (2010) }\end{array}$ \\
\hline & $\begin{array}{c}\text { Return on Sales } \\
\text { (ROS) }\end{array}$ & Net Income / Sales & $\begin{array}{c}\text { Waddock, Graves (1997); Callan, } \\
\text { Thomas (2009) }\end{array}$ \\
\hline
\end{tabular}

Source: Research data

In the data processing was adopted the canonical correlation analysis, which, according to Fávero (2005), is a multivariate technique that allows the researcher to examine the association of several dependent variables with several explanatory variables simultaneously, which can be both metric or non-metric, as expressed in Equation 1:

$$
Y_{1}+Y_{2}+Y_{3}+\ldots+Y_{n}=X_{1}+X_{2}+X_{3}+\ldots+X_{n}
$$

In which

$$
\text { (metric, non-numeric) (metric, non-numeric) }
$$

$\mathrm{Y}=$ dependent variables, or criterion,

$\mathrm{X}=$ Independent variables, or predictor. 
Since the purpose of the canonical correlation is to establish the relationship between two sets of variables, this technique is used expansively to assist the choice of statistical techniques to be used and to determine the variables that are more appropriate to the study. However, as Fávero et al. (2005) point out, the method has limitation on the sample size. When the samples are small, the correlations conceal significant relationships, that is, they exhibit correlations of variables that had to be both significant and not significant as well. Thus, it has been suggested that the sample shows, at least, ten observations for each variable, including the explanatory and dependent ones.

Hair et al. (2005, p. 375) argue that the canonical correlation provides evidence that allows researchers to infer the verification of variables in a beneficial relationship. Thus, the method enables "to combine in the form of composite measure what might otherwise be a large intractable number of bi-varied correlations among sets of variables." In addition, Hair et al. (2005, p. 375) also claim that the canonical correlation "is useful for identifying general relationships among multiple independent and dependent variables, particularly when the researcher has little previous knowledge of the relationships among sets of variables".

\section{Data Description and Analysis}

To reach the goal of analyzing the relationship of ownership concentration on economic and financial performance of Latin American companies was applied the canonical correlation analysis combining both sets of variables, the group ownership concentration and the group of variables of economic and financial performance, described in Table 2 as 'variables used in the study'.

At first, canonical correlation was performed for the total group of Latin American companies with ADR issuance. The results are shown in Table 1, indicating the canonical correlation for all Latin American countries. Thus, are observed in the first column four different linear combinations, since this is the number of the set of variables of group of economic and financial performance. This is smaller than the set of variables in the group of indicators of ownership structure. In turn, the second, third and fourth columns in Table 3 depict information concerning the Chi-square test, carried out to test the significance of the linear combinations calculated. The next column (D.F.) shows the degrees of freedom of each linear combination.

Table 3. Canonical correlation for all Latin American countries

\begin{tabular}{lllllll}
\hline Number & Self Value & Correlation & Lambda & Chi-square & F.D. & P-Value \\
\hline 1 & 0,374 & 0,612 & 0,456 & 300,184 & 32,000 & 0,000 \\
2 & 0,176 & 0,419 & 0,729 & 120,932 & 21,000 & 0,000 \\
3 & 0,074 & 0,272 & 0,884 & 47,086 & 12,000 & 0,000 \\
4 & 0,045 & 0,212 & 0,955 & 17,635 & 5,000 & 0,003 \\
\hline
\end{tabular}

Source: Research data

It is noted in Table 3 that the correlation in the first linear combination between the ownership structure group and the economic and financial performance was of $61.2 \%$, there existing a strong positive association, since the level of significance in the first linear combination is lower than $0.05(0.00)$, presented by p-value. Additional combinations have also shown significance lower than $5 \%$.

Table 4 shows the coefficients for the canonical variables of ownership structure group and of economic and financial performance group for all Latin American countries. According to Fávero et al. (2009), it is from the coefficients shown in Table 4 that the canonical variables are generated. For this study will be used only the coefficients described in the first column. This is the first linear combination, i.e., the one that has higher correlation among the four linear combinations calculated.

The coefficients shown in the remaining columns of Table 4 portray the calculation of the other three linear combinations. However, since the goal of the canonical correlation is to identify the two vectors whose correlation is the highest possible among themselves, only the first pair of vectors was used, since these are fulfilling the purpose of the model. 
Table 4. Coefficients for canonical variables of ownership structure group and economic and financial performance group for all Latin American countries studied

\begin{tabular}{llllll}
\hline Group & Variables & \multicolumn{4}{l}{ Linear Combinations } \\
\hline & & $\mathbf{1}$ & $\mathbf{2}$ & $\mathbf{3}$ & $\mathbf{4}$ \\
\hline & Tangibility. & 0,123 & $-0,352$ & $-0,352$ & 0,082 \\
& Assets' Side Value & 0,056 & $-0,202$ & $-0,164$ & $-0,118$ \\
& OBFNE & 0,012 & 0,056 & $-0,721$ & $-0,261$ \\
Property Structure & Singularity & $-0,943$ & $-0,012$ & $-0,231$ & $-0,055$ \\
& Size & 0,091 & 0,234 & $-0,077$ & 0,678 \\
& ETC & 0,280 & $-0,767$ & 0,007 & $-0,251$ \\
& ECPC & $-0,294$ & $-0,182$ & $-0,005$ & 1,095 \\
& ELPC & $-0,045$ & $-0,014$ & 0,170 & $-0,634$ \\
\hline \multirow{3}{*}{ Economic and Financial Performance } & LOAT & 0,198 & $-0,294$ & $-1,385$ & $-0,184$ \\
& ROA & $-0,526$ & 1,308 & 0,479 & $-0,329$ \\
& ROE & $-0,177$ & $-0,195$ & 0,129 & 1,181 \\
& ROS & 1,147 & $-0,097$ & 0,376 & 0,045 \\
\hline R1-Canonical Correlation & & 0,612 & 0,419 & 0,272 & 0,212 \\
\hline
\end{tabular}

Source: 2014 Research data

It is observed in Table 4 that the canonical coefficients corresponding to the first canonical pair show a tendency that the highest total indebtedness (ETC) (0.280) and the greatest tangibility (0.123) are determinants of the lowest return on assets (-0.526) and the highest return on sales (1.147). In other words, the smaller the company's return on total assets the more indebted it will be and the more inventory and fixed assets it will have. So, this happens also with the return on sales (ROS, 1,147): the higher the sales turnover of the company, the lower the selling expenses (Singularity, -0.943 ) and the higher its indebtedness. Since the company may have large inventories, those payable and the sales were not carried out as planned, thus generating greater indebtedness.

Table 5 shows information related to the Chi-square test, carried out to test the significance of calculated linear combinations. The next column (DF) shows the degrees of freedom of the linear combination that possesses higher correlation for each country portrayed separately.

Table 5. Canonical correlation for each Latin American country

\begin{tabular}{lllllll}
\hline Country & Self-Value & Correlation & Lambda & Chi-Square & D.F. & P-Value \\
\hline Mexico & 0,933 & 0,966 & 0,030 & 307,055 & 32,000 & 0,000 \\
Chile & 0,919 & 0,959 & 0,002 & 171,560 & 32,000 & 0,000 \\
Argentina & 0,873 & 0,935 & 0,010 & 149,766 & 32,000 & 0,000 \\
Brazil & 0,537 & 0,733 & 0,338 & 192,753 & 32,000 & 0,000 \\
Venezuela & 0,956 & 0,978 & 0,002 & 45,969 & 32,000 & 0,052 \\
\hline
\end{tabular}

Source: 2014 Research data

It is observed in Table 5 that the correlation with higher significance for Mexico (96.6\%), followed by Chile (95.9\%), Argentina (93.5\%) and Brazil (73.3\%), Venezuela (97.8\%), have shown the best correlation. However, the P-Value did not have significance lower than $5 \%$. Colombia and Peru, due to few observations, did not show any results. As recommended by Fávero et al. (2009), at least ten observations must be shown in relation to each variable.

Thus, one sees that the best performing country is Mexico. So, will be analyzed in Table 4 the coefficients shown in the remaining columns of Table 6, which depict the calculation of the four linear combinations. However, since the objective of the canonical correlation is to identify the two vectors, whose correlation is the highest possible among themselves, was used only the first pair of vectors because they fulfill the purpose of the model. These results corroborate the findings of Perobelli and Famá (2003). 
Table 6. Coefficients for canonical variables of ownership structure group and economic and financial performance group for Mexico

\begin{tabular}{cccccc}
\hline Group & Variables & \multicolumn{4}{c}{ Linear Combinations } \\
\hline & & $\mathbf{1}$ & $\mathbf{2}$ & $\mathbf{3}$ & $\mathbf{4}$ \\
\hline & Tangibility & 0,012 & $-0,058$ & 0,247 & $-1,402$ \\
& Assets' Side Value & 0,138 & $-0,147$ & 0,124 & $-1,199$ \\
& OBFNE & 0,061 & 0,210 & $-1,099$ & 1,126 \\
& Singularity & $-0,969$ & $-0,284$ & $-0,005$ & $-0,246$ \\
& Size & $-0,070$ & $-0,812$ & $-0,185$ & $-0,572$ \\
& ETC & $-0,043$ & 0,331 & 0,026 & $-0,943$ \\
& ECPC & $-0,111$ & $-0,273$ & $-0,050$ & 0,225 \\
& ELPC & $-0,028$ & 0,475 & $-0,418$ & $-0,133$ \\
\hline Economic and Financial Performance & LOAT & $-0,004$ & $-0,434$ & $-1,909$ & $-0,044$ \\
& ROA & 0,052 & $-1,273$ & 2,535 & $-1,732$ \\
& ROE & $-0,217$ & 0,166 & $-1,192$ & 2,044 \\
& ROS & 1,071 & 1,032 & 0,238 & 0,279 \\
\hline
\end{tabular}

Source: 2014 Research data

It is observed in table 6 that the canonical coefficients corresponding to the first canonical pair portray the tendency that a higher collateral value of assets (intangible, 0.138) and greater tax benefits than debt (OBFNE, 0.061) are determinants of lower return on equity of the company (ROE, -0.217). The higher the return that the organization has on sales (ROS, 1.071), the lower its short-term debt is (ECPC, -0.111). This is due to possible increases on the sales of the organization's activity products. Consequently, the company will make its short-term payments.

These results are analyzed from a macro perspective considering Latin American countries, understanding somehow the economy of each country and distinguishing their results. The companies analyzed in this study need to adapt themselves to higher levels and insert more rigid instruments of protection of minority shareholders, because they possess issuance of ADRs, with traded and active shares on New York Stock Exchange (NYSE), American Stock Exchange (AMEX) and on National Association of Securities Dealers Automated Quotation (NASDAQ). These results resemble the statements mentioned by Simerly and Li (2000), since the companies operating in stable environments show better performance, thus leveraging their profits.

Finally, the findings reveal to researchers and investors a better analysis, considering the country and company one may wish to invest in together with improving investigations. A keen analysis by companies holding better results on the ownership structure depicts more security for investments made. In general, the capital structure decisions are tied directly to the results of organizations, reflecting on the economic and financial performance. Therefore, the results corroborate from a macro view the studies by SIMERLY, LI, 2000; LIMA; BRITO, 2003; PEROBELLI; FAMÁ, 2003; PROCIANOY; SCHNORRENBERGER, 2004; SILVA; MAJLUF; PAREDES, 2006.

\section{Concluding Considerations}

This study has examined the relationship of ownership concentration in the financial performance of publicly traded Latin American companies, whose American Depository Receipts (ADRs) involve more rigid instruments of protection of minority shareholders. The study period has comprised the years 2008 to 2012 and the data were collected by means of Thomson ${ }^{\circledR}$ database. The model applied in the study tested a group of variables related to indicators of property and another group of variables of financial performance. These variables have already been tested by other studies listed in Table 2, titled 'variables used in the study'.

In general, the decisions on capital structure are directly tied to the results of the organization and reflect on the economic and financial performance. Thus, the results reinforce the findings of Simerly and Li (2000), Lima and Brito (2003), Perobelli and Fama (2003), Procianoy and Schnorrenberger (2004), Silva, Majluf and Paredes (2006).

The correlation between the set of variables pertaining to ownership structure variables group with the variable group of financial performance has depicted significant correlation of 5\% for linear combinations, when analyzed in the set of all the companies and when analyzed separately per country, except for Venezuela that was above 5\%, and Colombia and Peru, which had not obtained the correlation due to the existence of a few observations.

Finally, the results show higher significant correlation of (0.966) to Mexico, when compared with the results of other countries between the set of the two groups of variables of ownership structure and the economic and financial performance analyzed. 
It is expected that the results presented in this study be expanded and supplemented. In this regard, it is suggested that further research seek to investigate the influence of concentration of ownership on the capital structure decisions of countries with distinct characteristics, including longer periods and other variables.

\section{References}

Aldrighi, D. M., \& Mazzer, N. R. (2005). Estrutura de propriedade e de controle das empresas de capital aberto no Brasil. Revista de Economia Política, 25(2), 115-137. https://doi.org/10.1590/S0101-31572005000200009.

Assaf, N. A. (2003). Finanças corporativas e valor. Atlas.

Assaf, N. A. (2012). Finanças corporativas e valor. 6. ed. São Paulo: Atlas.

Bastos, D. D., \& Nakamura, W. T. (2009). Determinantes da estrutura de capital das companhias abertas no Brasil, México e Chile no período 2001-2006. Revista Contabilidade \& Finanças, 20(50), 75-94. https://doi.org/10.1590/S1519-70772009000200006.

Bastos, D. D., Nakamura, W. T., \& Basso, L. F. C. (2009). Determinantes da estrutura de capital das companhias abertas na América Latina: um estudo empírico considerando fatores macroeconômicos e institucionais. Revista de Administração Mackenzie (Mackenzie Management Review), https://doi.org/10.1590/S1678-69712009000600005.

Bhagat, S., \& Bolton, B. (2008). Corporate governance and firm performance. Journal of corporate finance, 14(3), 257-273. https://doi.org/10.1016/j.jcorpfin.2008.03.006

Callan, S. J., \& Thomas, J. M. (2009). Corporate financial performance and corporate social performance: an update and reinvestigation. Corporate Social Responsibility and Environmental Management, 16(2), 61-78. https://doi.org/10.1002/csr.182.

Campos, T. L. C. (2006). Estrutura da propriedade e desempenho econômico: uma avaliação empírica para as empresas de capital aberto no Brasil. Revista de Administração da Universidade de São Paulo, 41(4).

Capobiango, R. P., Abrantes, L. A., Ferreira, M. A. M., \& Faroni, W. (2012). Desempenho financeiro: um estudo com empresas de três diferentes setores. Revista de Ciências Humanas, 12(1), 165-180.

Cervo, A. L., Bervian, P. A., \& Silva, R. (2007). da. Metodologia Científica. 6. ed. São Paulo: Pearson Prentice Hall.

Céspedes, J., González, M., \& Molina, C. A. (2010). Ownership and capital structure in Latin America. Journal of business research, 63(3), 248-254. https://doi.org/10.1016/j.jbusres.2009.03.010.

Collis, J., \& Hussey, R. (2005). Pesquisa em administração: um guia prático para alunos de graduação e pós-graduação. Porto Alegre: Bookman.

Correa, C. A., Basso, L. F. C., \& Nakamura, W. T. (2013). The capital structure of largest Brazilian firms: an empirical analysis of the Pecking Order and trade-off theories, using panel data. RAM. Revista de Administração Mackenzie, 14(4), 106-133. https://doi.org/10.1590/S1678-69712013000400005.

Costa, F., \& Garcias, P. M. (2009). Concentração de mercado e desempenho das indústrias brasileiras de papel e celulose-recorrendo à modelagem de Fleuriet para analisar o paradigma ECD. Revista de Contabilidade $e$ Organizações, 3(6), 143-163. https://doi.org/10.11606/rco.v3i6.34745.

Dami, A. B. T., Rogers, P., \& de Sousa, R. K. C. (2007). Estrutura de propriedade no Brasil: evidências empíricas no grau de concentração acionária. Contextus-Revista Contemporânea de Economia e Gestão, 5(2).

Ehrhardt, M. C., \& Brigham, E. F. (2012). Administração financeira: teoria e prática. São Paulo: Cengage Learning.

Espinola, L. F. P. (2013). Determinantes da estrutura de capital na crise financeira global (Doctoral dissertation, Universidade de São Paulo).

Fávero, L. P., Belfiore, P., Silva, F. D., \& Chan, B. L. (2009). Análise de dados: modelagem multivariada para tomada de decisões.

Ferreira, J. A. S. (2005). Finanças corporativas: conceitos e aplicações. Pearson Prentice Hall.

Fischmann, A. A., \& Zilber, M. A. (1999). Utilização de indicadores de desempenho como instrumento de suporte à gestão estratégica. encontro da ANPAD, XXIII, Anais.

Fronningen, L. A., \& Van der Wijst, N. (2009). Ownership structure and performance of the largest German companies.

Gartner, I. R. (2010). Modelagem multiatributos aplicada à avaliação do desempenho econômico-financeiro de empresas. Pesquisa Operacional, 30(3), 619-636. https://doi.org/10.1590/S0101-74382010000300007. 
Gil, A. C. (2011). Métodos e Técnicas de Pesquisa Social. $6^{a}$ ed.- 4. Reimpr. - São Paulo: Atlas, 2011.

Gitman, L. J. (2004). Princípios de administração financeira, 10 edição. Tradução técnica Antônio Zoratto Sanvicente.

Gomes, G. L., \& Leal, R. P. C. (2001). Determinantes da estrutura de capitais das empresas brasileiras com ações negociadas em bolsas de valores. Finanças Corporativas. Atlas, São Paulo.

Hair, J. F., Anderson, R. E., Tatham, R. L., \& Black, W. C. (2005). Análise multivariada de dados. 5 ed. Porto Alegre: Bookman, 2005.

Iudícibus, S. (2008). Análise de Balanços. 9ª ed. São Paulo: Atlas.

Kayo, E. K. (2002). A estrutura de capital e o risco das empresas tangível e intangível-intensivas: uma contribuição ao estudo da valoração de empresas (Doctoral dissertation, Universidade de São Paulo).

Lang, L., Ofek, E., \& Stulz, R. (1996). Leverage, investment, and firm growth. Journal of financial Economics, 40(1), 3-29. https://doi.org/10.1016/0304-405X(95)00842-3.

Leal, R. P. C., \& Saito, R. (2003). Finanças corporativas no Brasil. RAE eletrônica, 2(2), 1-15. https://doi.org/10.1590/S1676-56482003000200005.

Leal, R. P. C., Silva, A. L. C. D., \& Valadares, S. M. (2002). Estrutura de controle das companhias brasileiras de capital aberto. Revista de Administração Contemporânea, 6(1), 7-18. https://doi.org/10.1590/S1415-65552002000100002.

Lefort, F., \& Walker, E. (2000). Ownership and capital structure of Chilean conglomerates: Facts and hypotheses for governance. Revista Abante, 3(1), 3-27.

Lima, M. R., \& Brito, R. D. (2010). O que Determina a Estrutura de Capital no Brasil?. ENCONTRO BRASILEIRO DE FINANÇAS, 3.

Marcon, R., Grzebieluckas, C., Bandeira-de-Mello, R., \& Muller, R. de A. (2007). O comportamento da estrutura de capital e a performance de firmas brasileiras, argentinas e chilenas. REGE Revista de Gestão, 14(2), 33-48.

Miller, M. H. (1977). Debt and taxes. the Journal of Finance, 32(2), 261-275.

Modigliani, F., \& Miller, M. H. (1958). The cost of capital, corporation finance and the theory of investment. The American economic review, 48(3), 261-297.

Morales, M., Meléndez, M. J., \& Ramírez, V. (2013). Determinantes de la concentración de la propiedad en el mercado de valores chileno. Revista Cepal.

Myers, S. C. (1977). Determinants of corporate borrowing. Journal of financial economics, 5(2), 147-175. https://doi.org/10.1016/0304-405X(77)90015-0.

Myers, S. C. (1984). The capital structure puzzle. The journal of finance, 39(3), 574-592. https://doi.org/10.1111/j.1540-6261.1984.tb03646.x.

Okimura, R. T. (2003). Estrutura de propriedade, governança corporativa, valor e desempenho das empresas no Brasil (Doctoral dissertation, Universidade de São Paulo).

Omran, M., \& Ragab, A. (2004). Linear versus non-linear relationships between financial ratios and stock returns: empirical evidence from Egyptian firms. Review of Accounting and Finance, 3(2), 84-102. https://doi.org/10.1108/eb043404.

Perez, M. M., \& Famá, R. (2004). Características estratégicas dos ativos intangíveis e o desempenho econômico das empresas no Brasil. VII SEMEAD-Seminários em Administração.

Perobelli, F. F. C., \& Famá, R. (2001). Fatores determinantes da estrutura de capital: aplicação a empresas de capital aberto no Brasil. Monografia. Universidade de São Paulo, Faculdade de Economia e Administração.

Perobelli, F. F. C., \& Famá, R. (2003). Fatores determinantes da estrutura de capital para empresas latino-americanas. Revista de Administração Contemporânea, 7(1), 9-35. https://doi.org/10.1590/S1415-65552003000100002

Perucelo, M. R., Prates, S. M., \& Espejo, R. A. (2009). As análises econômico-financeira tradicional e dinâmica e o desempenho percebido pelo mercado de ações: um estudo de empresas do setor têxtil e vestuário do Brasil no período de 1998 a 2007. Enfoque: Reflexão Contábil, 28(3).

Procianoy, J. L., \& Schnorrenberger, A. (2004). A influência da estrutura de controle nas decisões de estrutura de capital das companhias brasileiras. Revista Brasileira de Economia, 58(1), 122-146. https://doi.org/10.1590/S0034-71402004000100006. 
Roque, V., \& Cortez, M. D. C. (2006). A divulgação de informação ambiental ea performance financeira das empresas cotadas em Portugal. Tékhne-Revista de Estudos Politécnicos, (5-6), 119-143.

Santos, C. M., dos, Pimenta, J. T., \& Cicconi, E. G. (2009). Determinantes da escolha da estrutura de capital das empresas brasileiras de capital aberto: um survey. Revista de Administração-RAUSP, 44(1).

Shleifer, A., \& Vishny, R. W. (1997). A survey of corporate governance. The journal of finance, 52(2), 737-783. https://doi.org/10.1111/j.1540-6261.1997.tb04820.x.

Shyam-Sunder, L., \& Myers, S. C. (1999). Testing static tradeoff against pecking order models of capital structure1. Journal of financial economics, 51(2), 219-244. https://doi.org/10.1016/S0304-405X(98)00051-8

Silva, F., Majluf, N., \& Paredes, R. D. (2006). Family ties, interlocking directors and performance of business groups in emerging countries: The case of Chile. Journal of Business Research, 59(3), 315-321. https://doi.org/10.1016/j.jbusres.2005.09.004.

Silveira, A. D. M. da, Lanzana, A. P., Barros, L. A. B. D. C., \& Famá, R. (2004). Efeito dos acionistas controladores no valor das companhias abertas brasileiras. Revista de Administração da Universidade de São Paulo, 39(4).

Silveira, A. D. M. da. (2006). Governança corporativa e estrutura de propriedade: determinantes e relação com o desempenho das empresas no Brasil (Doctoral dissertation, Universidade de São Paulo).

Simerly, R. L., \& Li, M. (2000). Environmental dynamism, capital structure and performance: a theoretical integration and an empirical test. Strategic management journal, 21(1), 31-49. https://doi.org/10.1002/(SICI)1097-0266(200001)21:1<31::AID-SMJ76>3.0.CO;2-T.

Sousa, N. J. A., \& Martins, H. C. (2012). Finanças e Governança Corporativa: Práticas e Estudos de Caso. Elsevier Brasil.

Spiegel, M. R. (1993). Estatística. 3. ed. São Paulo: Makron Books, 1993.

Srour, G. (2005). Práticas diferenciadas de governança corporativa: um estudo sobre a conduta e a performance das firmas brasileiras. Revista Brasileira de Economia, 59(4), 635-674. https://doi.org/10.1590/S0034-71402005000400006.

Terra, P. R. S. (2007). Estrutura de capital e fatores macroeconômicos na América Latina. Revista de Administração-RAUSP, 42(2).

Titman, S., \& Wessels, R. (1988). The determinants of capital structure choice. The Journal of finance, 43(1), 1-19. https://doi.org/10.1111/j.1540-6261.1988.tb02585.x

Waddock, S. A., \& Graves, S. B. (1997). The corporate social performance-financial performance link. Strategic $\begin{array}{llr}\text { management } & \text { journal, } & \text { 303-319. }\end{array}$ https://doi.org/10.1002/(SICI)1097-0266(199704)18:4<303::AID-SMJ869>3.0.CO;2-G

Weston, J. F. (1974). New themes in finance. The Journal of Finance, 29(1), 237-243. https://doi.org/10.1111/j.1540-6261.1974.tb00039.x

\section{Copyrights}

Copyright for this article is retained by the author(s), with first publication rights granted to the journal.

This is an open-access article distributed under the terms and conditions of the Creative Commons Attribution license which permits unrestricted use, distribution, and reproduction in any medium, provided the original work is properly cited. 